\title{
The adjustment of neurosurgical procedures during the COVID-19 pandemic: a case study at Dr. Sardjito General Hospital as a part of an academic health system
}

\author{
Handoyo Pramusinto, MD,, Daniel Agriva Tamba, MD, MSc, ${ }^{1}$ Yoyok Subagio, MD, ${ }^{2}$ \\ Tommy J. Numberi, MD, ${ }^{3}$ Bangun Pramujo, MD, ${ }^{4}$ Franklin L. Sinanu, MD, ${ }^{5}$ \\ Gheanita Ariasthapuri, MD, ${ }^{6}$ Haryo Bismantara, MD, ${ }^{6}$ and Andreasta Meliala, MD, PhD ${ }^{6}$ \\ 1Division of Neurosurgery, Department of Surgery, Universitas Gadjah Mada, Yogyakarta, Special Region of Yogyakarta; \\ 2Division of Neurosurgery, Muhammadiyah University Hospital, Malang, East Java; ${ }^{3}$ Division of Neurosurgery, Jayapura General

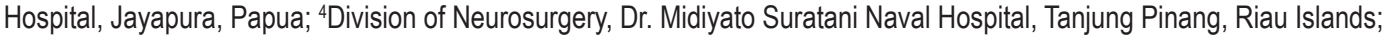 \\ ${ }^{5}$ Division of Neurosurgery, Undata General Hospital, Palu, Central Sulawesi; and ${ }^{6}$ Department of Health Policy and Management, \\ Universitas Gadjah Mada, Special Region of Yogyakarta, Indonesia
}

OBJECTIVE The recent COVID-19 outbreak has forced notable adjustments to surgical procedure preparation, including neurosurgical services. However, due to the uniqueness of the recent situation, neurosurgical centers, especially those located in low-resource settings, are facing several challenges such as a lack of coordination, poor equipment, and shortage of medical personnel. Therefore, several guidelines from local authorities and international neurosurgical bodies have been published to help clinicians manage their patients. In addition, the academic health system (AHS), which is an integrated system containing a medical institution, universities, and a teaching hospital, may play some role in the management of patients during COVID-19. The objective of this study was to describe how each hospital in the authors' network adjusted their neurosurgical practice and how the AHS of the Universitas Gadjah Mada (UGM) played its role in the adaptation process during the pandemic.

METHODS The authors gathered both local and national data about the number of COVID-19 infections from the government's database. To assess the contribution of the AHS to the efforts of each hospital to address the pandemic, questionnaires were given to 6 neurosurgeons, 1 resident, and 2 general surgeons about the management of neurosurgical cases during the pandemic in their hospitals.

RESULTS The data illustrate various strategies to manage neurosurgical cases by hospitals within the authors' networks. The hospitals were grouped into three categories based on the transmission risk in each region. Most of these hospitals stated that UGM AHS had a positive impact on the changes in their strategies. In the early phase of the outbreak, some hospitals faced a lack of coordination between hospitals and related stakeholders, inadequate amount of personal protective equipment (PPE), and unclear regulations. As the nation enters a new phase, almost all hospitals had performed routine screening tests, had a sufficient amount of PPE for the medical personnel, and followed both national and international guidelines in caring for their neurosurgical patients.

CONCLUSIONS The management of neurosurgical procedures during the outbreak has been a challenging task and a role of the AHS in improving patient care has been experienced by most hospitals in the authors' network. In the future, the authors expect to develop a better collaboration for the next possible pandemic.

https://thejns.org/doi/abs/10.3171/2020.9.FOCUS20699

KEYWORDS COVID-19; academic health system; middle-income country; neurosurgical procedure; Indonesia

OVID-19 has become a global public health problem in recent months, and its impact on surgery, including neurosurgical procedures, has been detailed in several articles., ${ }^{1,2}$ The deferral of elective surgery has been advocated by the majority of surgical or neurosurgical associations as well as governmental bodies. ${ }^{3,4}$ Such cancellations were intended to create more room for COVID-19 patients and to concentrate the hospital's lim-

ABBREVIATIONS AHS = academic health system; DSGH = Dr. Sardjito General Hospital; IDVI = Infectious Disease Vulnerability Index; ISNS = Indonesian Society of Neurological Surgeons; MIC = middle-income country; PCR = polymerase chain reaction; PPE = personal protective equipment; SOP = standard operating procedure; SPAR = State Party Self-Assessment Report; UGM = Universitas Gadjah Mada.

SUBMITTED August 1, 2020. ACCEPTED September 18, 2020.

INCLUDE WHEN CITING DOI: 10.3171/2020.9.FOCUS20699. 
ited resources (e.g., personal protective equipment [PPE] and healthcare workers) to manage the fast-growing number of COVID-19 cases. . $^{2,3,5}$

Neurosurgical service in Indonesia, a country at the middle-income country (MIC) level, has also been affected by the pandemic. A previous report described a significant reduction in the number of neurosurgical procedures in a hospital in Indonesia, a similar trend to the one that has occurred globally. ${ }^{6}$ Moreover, outpatient visits to the neurosurgery clinic were also reduced. Physical distancing and "stay at home" regulations imposed by the government had been associated with such a reduction and might have also contributed to reducing a medical facility's workload. ${ }^{6-8}$

Nevertheless, some nondeferrable cases were still present. Moreover, some centers continued to perform elective neurosurgical procedures. ${ }^{6}$ Various national and international bodies had published guidelines for neurosurgical patient management to maintain both staff and patient safety during those procedures. ${ }^{9}$ Therefore, there was a need for a quick adaptation by the clinicians in performing the surgeries using those recently published guidelines. Also, one of the foremost issues is how the information is utilized in a hospital with low resources, especially in the MICs.

The academic health system (AHS) is a concept that serves to provide healthcare services, education, and research by integrating degree-granting medical institutions with other programs of health professionals and one or more hospitals or teaching hospitals..$^{10,11}$ The role of the AHS in improving the quality of patient management has been described in several papers. ${ }^{12,13}$ Moreover, several public health responses to reduce the impact of COVID-19 in relation to the AHS's role have also been discussed. ${ }^{14}$ However, this evidence mostly came from developed countries, and it is vital to evaluate the impact of AHS on COVID-19 management in the developing world.

In this article, we describe the collaborative effort between the Division of Neurosurgery of Dr. Sardjito General Hospital (DSGH), a leading hospital in one AHS, and other neurosurgical centers within its hospital network in adapting to the recent pandemic. We also explain disruptions that affected neurosurgical procedures during the COVID-19 pandemic.

\section{Methods}

This article is a case study with the hospital network of the Division of Neurosurgery of DSGH as the unit analysis. Initially, we assess the nation's preparedness in handling the outbreak and level of vulnerability to the outbreak using the State Party Self-Assessment Report (SPAR) and Infectious Disease Vulnerability Index (IDVI), respectively. ${ }^{15,16}$ The higher the SPAR and IDVI score, the higher the capability and the lesser the vulnerability. Moreover, to provide a broad perspective on the situation during the pandemic in Indonesia, we present national and local COVID-19 infection data. We also created a map to show the number of cases per 100,000 population in the provinces where our hospital network is located (Fig. 1). All data were collected from the national database created by the Task Force for the Acceleration of COVID-19 Management (Gugus Tugas Percepatan Penanganan COVID-19) and the local government database of COVID-19.

To provide a clear understanding regarding the AHS of Universitas Gadjah Mada (UGM), we added information about its establishment from online university sources. Afterward, to describe each hospital's medical capacity, we used the hospital's classification system that was described in the Decree of Indonesian Ministry of Health No. 56 (2014) and the Government Ordinance No. 93 (2015), respectively. ${ }^{17,18}$ The list of hospitals within our network are presented in Table 1.

Furthermore, we collected data about the number of neurosurgical procedures, both elective and emergency, during the pandemic from each hospital within our network (Figs. 2 and 3). To describe how neurosurgical cases were handled in each hospital, we conducted a survey that contains a set of questions relating to the management of neurosurgical cases during the pandemic. Purposive sampling was performed. The subjects were 6 neurosurgeons from 6 hospitals, 1 neurosurgery resident from Yulidin Away General Hospital, and 1 general surgeon from UGM Academic Hospital. We created a different set of questions focusing on the general surgical preparation aspect in UGM Academic Hospital because this hospital did not provide any neurosurgical services. The analysis of the responses, which included free-text answers and yes/no questions, was then performed using qualitative content analysis techniques. ${ }^{19}$ The results were presented in three different categories, which depended on the region's transmission risk status (Table 2). ${ }^{20}$

\section{Results}

\section{The Recent Development of COVID-19 in Indonesia:} Indonesia Preparedness and Vulnerabilities

Indonesia's SPAR index score was 77.1, which illustrated a moderate capacity to address the COVID-19 pandemic. Indonesia's IDVI score was 56.2, indicating a moderate vulnerability to outbreak. Compared to the other 11 Association of Southeast Asian Nations members, Indonesia was ranked third and sixth, respectively, in terms of SPAR and IDVI score, with Singapore having the highest score for both metrics ( 98 and 88 , respectively).

As of July 6,2020, the number of cumulative cases has not yet reached its peak, with 64,958 confirmed cases and 3241 deaths reported, and the infection rate was still increasing. ${ }^{21}$ Nevertheless, on May 27, 2020, the Indonesian Ministry of Internal Affairs released a new regulation to relax the large-scale social restrictions that were previously established (Decree of Minister of Internal Affairs No. 440-830, 2020 [Kepmendagri No. 440-830 tahun 2020]). ${ }^{22}$ The large-scale social restrictions could be relaxed if a region fulfilled the following criteria: reduced number of positive cases, deaths, or transmission to medical personnel. ${ }^{22}$ Following the release of the decree, the Indonesian president announced that Indonesia entered a new phase, the "new normal" phase.

\section{Dr. Sardjito General Hospital: The Leading Hospital in the AHS}

In 2014, UGM established the AHS of UGM. Initial- 


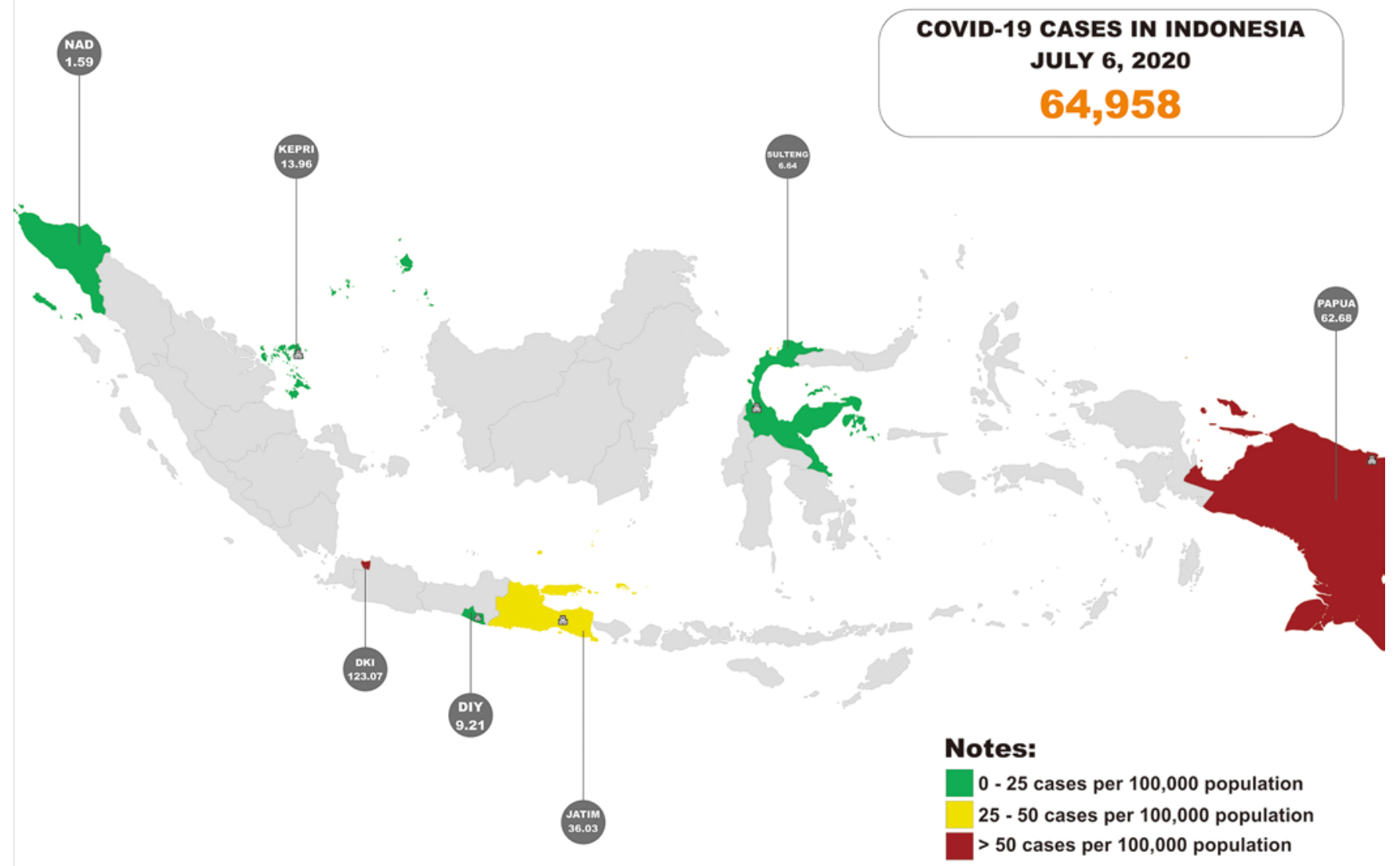

FIG. 1. The distribution map of COVID-19 cases in the provinces where the hospital network of DSGH is located. The small hospital logos depict the actual location of each hospital. On July 6, 2020, the number of COVID-19 cases in DKI Jakarta, Indonesia's capital, was second only to the number of cases in East Java. DIY = Daerah Istimewa Yogyakarta/Special Region of Yogyakarta; DKI = Daerah Khusus Ibukota Jakarta; JATIM = Jawa Timur/East Java; KEPRI = Kepulauan Riau/Riau Islands; NAD = Nangroe Aceh Darussalam; SULTENG = Sulawesi Tengah/Central Sulawesi.

ly, there were 5 hospitals within the system, including DSGH, Dr. Soeradji Tirtonegoro, UGM Academic Hospital, Banyumas General Hospital, and Dr. S. Hardjolukito Air Force Central Hospital. The concept was developed based on the Decree of UGM Rector (No. 1256/UN1.P/ SK/Hukor/2016). Finally, in 2017, Sleman General Hospital and Wates General Hospital also joined the AHS of UGM.

\section{High-Risk COVID-19 Transmission Areas \\ Jayapura, Papua}

Papua was among the provinces with a high number of COVID-19 patients. By July 7, 2020, there were 2027 cases of COVID-19 in Papua, which was approximately $3.1 \%$ of Indonesia's cumulative cases. The city of Jayapura was in the region with a moderate risk of transmission. Since April 2020, Jayapura General Hospital had not been able to perform elective procedures (Fig. 2). The hospital did not have any specialized operating theater for COVID-19, and the postoperative room was still in a developmental stage. Moreover, flooding that occurred in late April 2020 exacerbated the already-deprived conditions. ${ }^{23}$

Conversely, emergency procedures were still per- formed using more precautions, and there were no significant differences between the number of surgical operations pre- and post-outbreak (Fig. 3). All patients were tested for SARS-CoV-2 antibodies using a rapid test kit for initial COVID-19 detection before the surgery. The surgery would be postponed if the test yielded a positive result. Like other centers, the hospital staff followed recommendations from the Indonesian Society of Neurological Surgeons (ISNS) and local guidelines from the Papua government.

However, in the middle of July 2020, more than 110 employees at Jayapura General Hospital tested positive for COVID-19. Several possibilities might have caused this outbreak, but the most important factor might have been unclear regulations for hospital visitors. The visitors could enter the hospital without proper health checks and PPE, especially at night, when the guard staff was not available and the hospital's entry point was not guarded well. The failure to mitigate virus transmission from the visitors to healthcare workers and patients increased the possibility of a COVID-19 outbreak in the hospital. ${ }^{24}$ Consequently, following the outbreak, they could not perform emergency procedures because most of the workers were quarantined. 
TABLE 1. List of hospitals within our network

\begin{tabular}{|c|c|c|c|c|}
\hline Hospital \& Location & Type & $\begin{array}{l}\text { Relation w/ } \\
\text { UGM AHS }\end{array}$ & $\begin{array}{l}\text { Neurosurgical } \\
\text { Service }\end{array}$ & $\begin{array}{l}\text { Neurosurgeon } \\
\text { Availability }\end{array}$ \\
\hline Dr. Sardjito General Hospital, Sleman, Yogyakarta & A & Main academic hospital of UGM AHS & Yes & Yes \\
\hline $\begin{array}{l}\text { Universitas Gadjah Mada Academic Hospital, Yogyakarta, } \\
\text { Special Region of Yogyakarta }\end{array}$ & B & Satellite academic hospital of UGM AHS & No & No \\
\hline $\begin{array}{l}\text { Dr. S. Hardjolukito Air Force Central Hospital, Bantul, Special } \\
\text { Region of Yogyakarta }\end{array}$ & B & Satellite academic hospital of UGM AHS & Yes & Yes \\
\hline Wates General Hospital, Wates, Special Region of Yogyakarta & B & Satellite academic hospital of UGM AHS & No & No \\
\hline $\begin{array}{l}\text { Yulidin Away General Hospital, Tapaktuan, Nangroe Aceh } \\
\text { Darussalam }\end{array}$ & B & $\begin{array}{l}\text { Sister hospital of UGM neurosurgery } \\
\text { program }\end{array}$ & Yes & $\mathrm{No}^{*}$ \\
\hline $\begin{array}{l}\text { Dr. Midiyato Suratani Naval Hospital, Tanjung Pinang, } \\
\text { Riau Islands }\end{array}$ & B & $\begin{array}{l}\text { Neurosurgeon graduated from the UGM } \\
\text { neurosurgery program }\end{array}$ & Yes & Yes \\
\hline Muhammadiyah University Hospital, Malang, East Java & $\mathrm{C}$ & $\begin{array}{l}\text { Neurosurgeon graduated from the UGM } \\
\text { neurosurgery program }\end{array}$ & Yes & Yes \\
\hline Undata General Hospital, Palu, Central Sulawesi & B & $\begin{array}{l}\text { Neurosurgeon graduated from the UGM } \\
\text { neurosurgery program }\end{array}$ & Yes & Yes \\
\hline Jayapura General Hospital, Jayapura, Papua & B & $\begin{array}{l}\text { Neurosurgeon graduated from the UGM } \\
\text { neurosurgery program }\end{array}$ & Yes & Yes \\
\hline
\end{tabular}

Type A, B, and C hospitals represent tertiary, high-resource secondary, and low-resource secondary referral hospitals, respectively. The details about how a hospital is classified (i.e., type A, B, or C) are completely described in the Decree of Indonesian Ministry of Health No. 56 (2014) and the Government Ordinance No. 93 (2015).

${ }^{*}$ Neurosurgery service is provided by a neurosurgery resident, with supervision from our division.

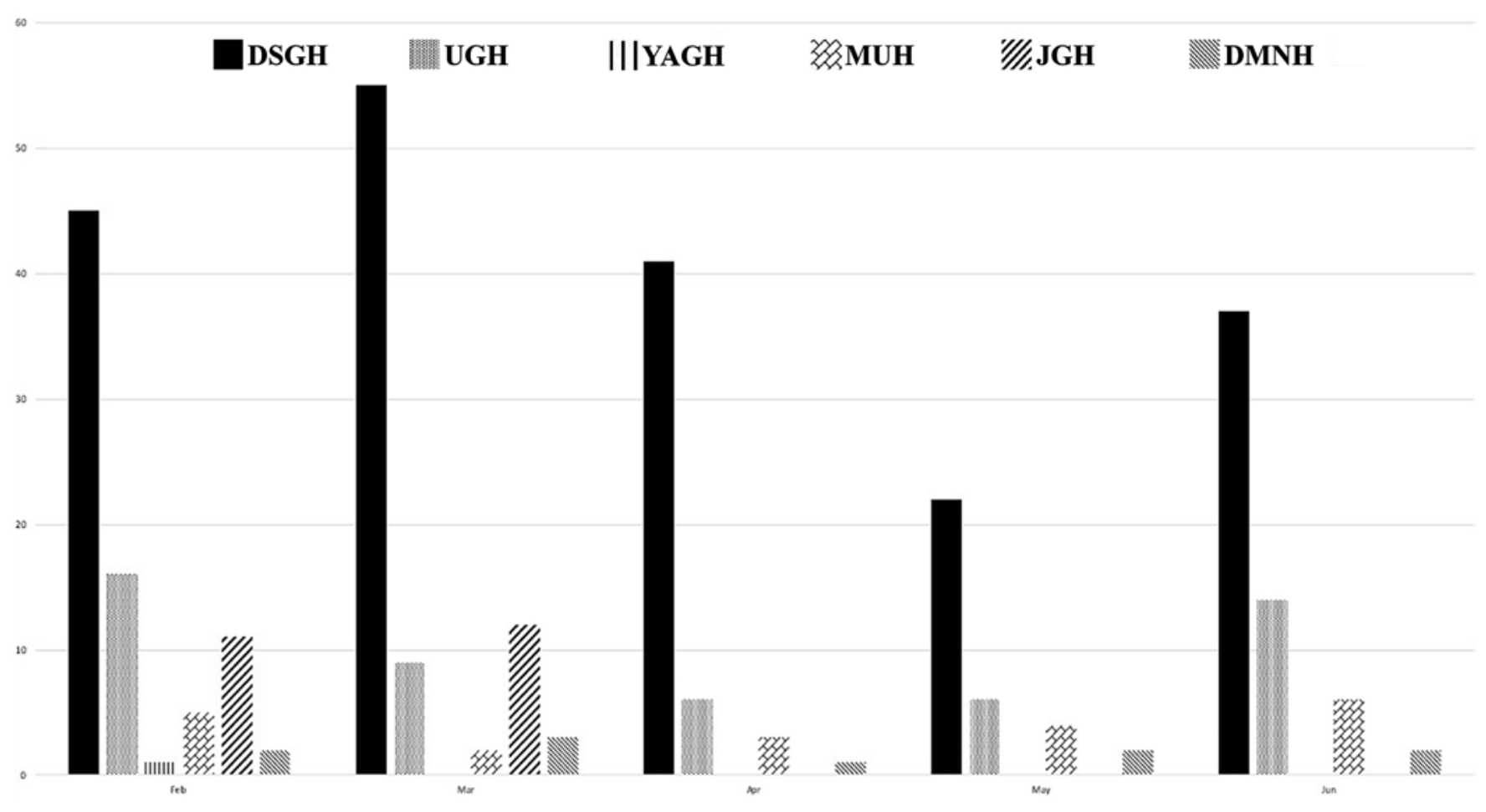

FIG. 2. Graph showing the number of neurosurgical elective procedures during the outbreak (March-June 2020) in DSGH and other hospitals within our network. We also present the number of procedures in February as a representation of the preCOVID-19 number of elective procedures in each hospital. UGH = Undata General Hospital; YAGH = Yulidin Away General Hospital; MUH = Muhammadiyah University Hospital; JGH = Jayapura General Hospital; DMNH = Dr. Midiyato Suratani Navy Hospital. 


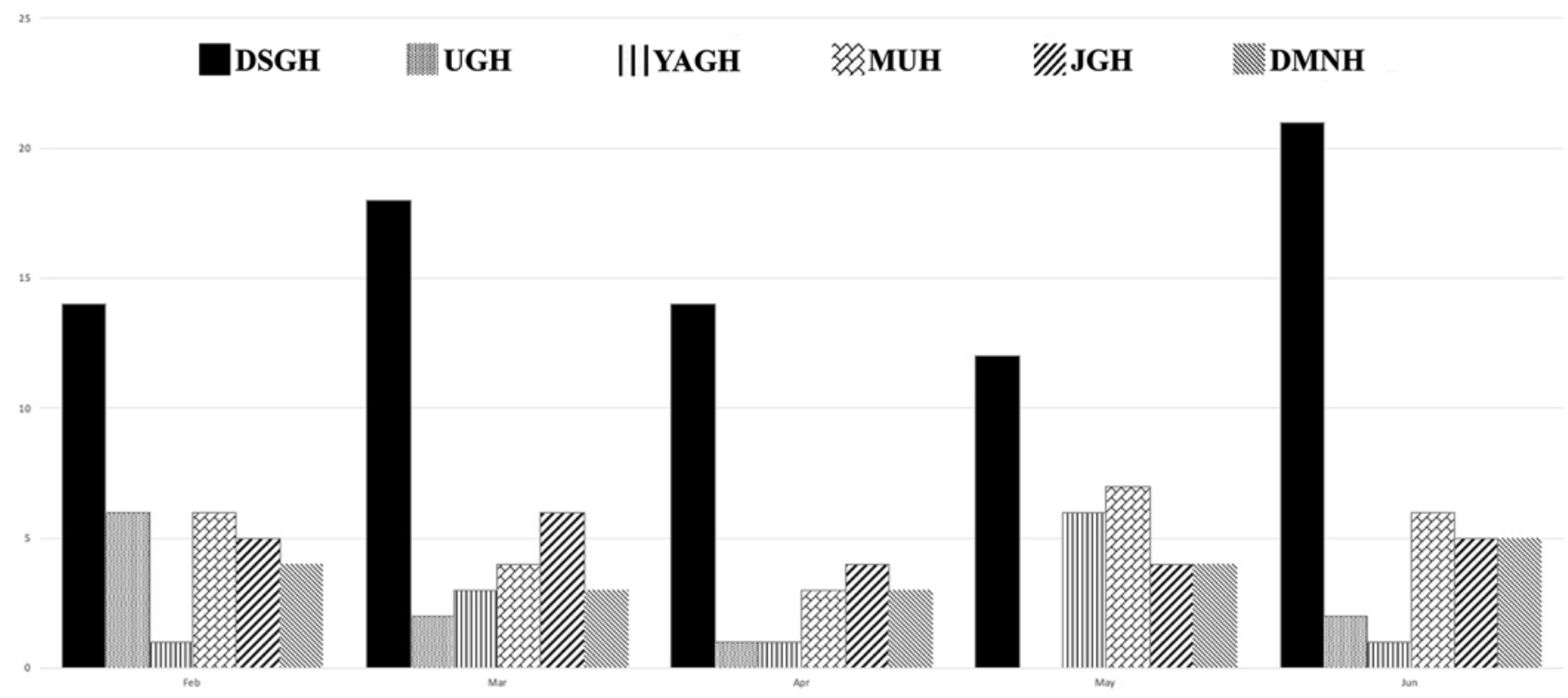

FIG. 3. Graph showing the number of neurosurgical emergency procedures during the outbreak (March-June 2020) in DSGH and other hospitals within our network. We also present the number of procedures in February as a representation of the pre-COVID-19 number of emergency procedures in each hospital.

\section{Malang, East Java}

On July 4, 2020, East Java was the province with the highest number of COVID-19 cases in Indonesia. ${ }^{25}$ There were 14,578 cases (22\% of national cases), with 1112 fatalities. ${ }^{26}$ As for Malang, there were 278 patients (1.9\% of cases in East Java) who were COVID-19 positive. ${ }^{26} \mathrm{Mu}-$ hammadiyah University Hospital in Malang, one of our hospital networks, was selected as one of the referral hospitals. Due to the inadequate amount and quality of the PPE and related infrastructure, they could not perform emergency procedures for several days in April 2020, hence the reduction of operative procedures (Fig. 3). They adapted a recommendation from the ISNS to create hospital guidance for treating neurosurgical patients. Before each operative procedure, the patient was screened for COVID-19 using a SARS-CoV-2 antibody test kit. If the test was positive, they conducted a polymerase chain reaction (PCR) test. If a neurosurgical patient needed an elective surgical procedure but tested positive for COVID-19, the hospital would send the patient to a tertiary referral hospital for further management.

\section{Moderate-Risk COVID-19 Transmission Areas \\ Sleman, Special Region of Yogyakarta}

On July 6, 2020, Sleman was the only regency with "moderate" status of transmission risk in the Special Region of Yogyakarta. ${ }^{20}$ There were 133 confirmed cases (around $39 \%$ of Yogyakarta cases) and 5 deaths in Sleman until July 6, 2020. ${ }^{27}$ DSGH was located in Sleman, and the state of neurosurgical procedures until mid-April had been discussed in our previous report. ${ }^{6}$ The number of both elective and emergency cases continued to decrease and reached its lowest total in May 2020. In June 2020, the number of operative cases experienced a rebound (Figs. 2 and 3).
UGM Academic Hospital, another COVID-19 referral hospital, did not have any neurosurgeons. Therefore, our focus shifted on how they managed a neurosurgical patient in the emergency room. The hospital used a guideline from the Indonesian General Surgeon Society to create a standard operating procedure (SOP) for general surgery cases and stated that they were entirely able to implement the guideline. ${ }^{28}$ In the prehospital phase, for example, they screened each patient who needed an emergency service for COVID-19 by asking whether there were any symptoms related to COVID-19. After reaching the hospital, the doctor would order a chest radiograph and a rapid test for SARS-CoV-2 antibodies.

TABLE 2. COVID-19 zonation risk data of each region where the hospitals are located

\begin{tabular}{lcc}
\hline \multicolumn{1}{c}{ Province } & City/Regent & Risk Status* \\
\hline \multirow{2}{*}{$\begin{array}{l}\text { Special Region of } \\
\text { Yogyakarta }\end{array}$} & Yogyakarta & Low \\
\cline { 2 - 3 } & Bantul & Low \\
\cline { 2 - 3 } & Wates & Low \\
\cline { 2 - 3 } Nangroe Aceh Darussalam & Sleman & Moderate \\
\hline Riau Islands & Tapaktuan & Low \\
\hline East Java & Malang & Low \\
\hline Central Sulawesi & Palu & Low \\
\hline Papua & Jayapura & High \\
\hline
\end{tabular}

* Based on data on July 6, 2020, from: Gugus Tugas Percepatan Penanganan COVID-19. Zonation risk data. Published 2020. Accessed October 15, 2020. https://covid19.go.id/peta-risiko. 


\section{Low-Risk COVID-19 Transmission Areas}

\section{Bantul, Special Region of Yogyakarta}

As of July 6, 2020, the Bantul regency was the region with the second highest number of COVID-19 cases in Yogyakarta (88 positive cases). Dr. S. Hardjolukito General Hospital was one hospital that was chosen to treat COVID-19 patients. Due to the relatively low number of COVID-19 cases in the region, this hospital was able to manage neurosurgical patients who needed either emergency or elective procedures. They screened all new patients for COVID-19 using a qualitative kit to test antibodies against the SARS-CoV-2 virus. If the patient tested positive for COVID-19 and, at the same time, needed a surgical procedure, the medical team would send the patient to our center.

During each procedure, they used proper PPE, just as suggested by the Task Force for the Acceleration of COVID-19 Management. ${ }^{29}$ In the early phase of the outbreak, there was a scarcity of PPE in the Bantul region. Consequently, this resulted in a higher number of unnecessary referrals to our center. However, this problem was immediately resolved by the creation of a better scoring system and a better supply of PPE in Yogyakarta.

\section{Tapaktuan, Nangroe Aceh Darussalam}

Until July 4, 2020, the total number of COVID-19 confirmed cases in Nangroe Aceh Darussalam was 87, which was approximately $0.1 \%$ of the national cases. ${ }^{25}$ Recently, the regional government has published a list of regional zonation based on COVID-19 impact on each area (Governor circular letter no. 440/7810, 2020). ${ }^{30}$ The South Aceh regency and Tapaktuan, its capital, were included in the green zone, with a low number of confirmed cases. Therefore, there were no significant changes in medical services in these regions. In Yulidin Away General Hospital, emergency procedures were still performed, with a significant reduction in April and May 2020 (Fig. 3). However, there were no elective cases from March through June 2020 (Fig. 2). To maintain their personnel's safety, the hospital adapted the recommendations published by ISNS because they were deemed more relatable by the staff.,31,32 Additional preoperative procedures, such as COVID-19 screening using a SARS-CoV-2 antibody test kit, were performed before each procedure.

\section{Tanjung Pinang, Riau Islands}

In the 1st week of April 2020, Dr. Midiyato Suratani Naval Hospital had not performed any elective procedures. This decision was made for several reasons, such as an inadequate amount of PPE and no operating theater specially dedicated to COVID-19 cases. There were also issues regarding the use of PPE, such as fear from the staff that N95 masks might interrupt their breathing or face mask use might taint the aseptic condition of the surgical gloves, gowns, and operative views. After several improvements in these issues, both elective and emergency procedures were resumed. Consequently, the numbers of both procedures were slightly improved in May 2020 (Figs. 2 and 3). The neurosurgical staff decided to follow guidance from the ISNS to perform surgical procedures. They screened all emergency patients for COVID-19 using SARS-CoV-2 antibody detection kits. In terms of operative procedures, the neurosurgical team entered the operating theater about 17 minutes later than the anesthesiologist, which was expected to reduce the risk of droplet transmission from the aerosol-generating process, such as intubation.

\section{Palu, Central Sulawesi}

As of July 6, 2020, the number of COVID-19 cases was 191 ( $0.3 \%$ of national cases) in Central Sulawesi, in which 10 of 13 cities/regencies were categorized as having low risk of transmission. In Palu, Undata General Hospital was still able to perform both emergency and elective surgical procedures. The administrator followed the recommendations from the American College of Surgeons (i.e., Elective Surgery Acuity Scale) and ISNS due to the simplicity of these two guidelines. The hospital did not have an established operating room designed for COVID-19 patients; however, the hospital owned a temporary operating theater that was donated by the ISNS.

Moreover, they included additional tests such as a COVID-19 rapid test (SARS-CoV-2 antibody) for preoperative patients. If a patient tested positive for COVID-19, he or she had to undergo a PCR test, and any elective procedure would be deferred. If the patient needed an emergency procedure, the surgery would be performed in the temporary operating theater for COVID-19. In general, there was a decrease in the number of neurosurgical cases (Figs. 2 and 3). Such decline in the number of neurosurgical patients enabled the hospital to reduce the staff's working hours, from 3 staff members each day to 1-2 persons per day. The PPE usage was adjusted to the type of surgical procedure, where level 3 PPE would be used in a procedure involving paranasal sinuses and any procedure that might produce aerosolization. Neurosurgical staff in Undata General Hospital believed that they could implement the COVID-19 guidelines properly due to proper regulations from the local government and significant awareness from the citizens to limit their visits to the hospital.

\section{Collaboration of DSGH and Its Hospital Network During the Pandemic}

To assess the impact of the UGM AHS, we asked respondents about the type of partnership that was performed and how such activities affected the quality of neurosurgical care during the pandemic. Five of 7 hospitals stated that DSGH had positive roles in the adaptation process of neurosurgical services (Table 3). Most of the respondents had routine live discussions via several platforms (e.g., Zoom or WhatsApp messenger) with our centers. In this discussion, the information about the SOP for managing patients during the pandemic, newly released COVID-19related guidelines (both national and international), the number of COVID-19 patients who were treated in each hospital, or the availability of PPE to the hospital members was usually shared between the participants.

\section{Discussion}

Recent Development of COVID-19 in Yogyakarta: Entering a "New Normal" Phase

We divided the pandemic into four phases: phase 1 (the 
TABLE 3. The collaboration of DSGH and its hospital network during the COVID-19 outbreak

\begin{tabular}{|c|c|}
\hline Hospital Network & Type of Activity w/ DSGH Division of Neurosurgery During the Pandemic \\
\hline $\begin{array}{l}\text { Universitas Gadjah Mada Academic Hospital, } \\
\text { Yogyakarta, Special Region of Yogyakarta }\end{array}$ & $\begin{array}{l}\text { Routine communication by phone to discuss the management of general surgery cases, especially } \\
\text { cases that needed to be referred }\end{array}$ \\
\hline $\begin{array}{l}\text { Dr. S. Hardjolukito Air Force Central } \\
\text { Hospital, Bantul, Special Region of } \\
\text { Yogyakarta }\end{array}$ & $\begin{array}{l}\text { 1) Routine communication by phone to discuss the management of general surgery cases, especially } \\
\text { cases that needed to be referred } \\
\text { 2) The latest information regarding COVID-19 cases and its management in Dr. S. Hardjolukito } \\
\text { Hospital was routinely discussed every Tuesday; the case was presented by a resident who was } \\
\text { stationed in the hospital }\end{array}$ \\
\hline $\begin{array}{l}\text { Wates General Hospital, Wates, Special } \\
\text { Region of Yogyakarta }\end{array}$ & No specific activities \\
\hline $\begin{array}{l}\text { Yulidin Away General Hospital, Tapaktuan, } \\
\text { Nangroe Aceh Darussalam }\end{array}$ & Knowledge transfer regarding the creation of SOPs to screen new patients for COVID-19 \\
\hline $\begin{array}{l}\text { Dr. Midiyato Suratani Naval Hospital, } \\
\text { Tanjung Pinang, Riau Islands }\end{array}$ & No specific activities \\
\hline $\begin{array}{l}\text { Muhammadiyah University Hospital, } \\
\text { Malang, East Java }\end{array}$ & No specific activities \\
\hline $\begin{array}{l}\text { Undata General Hospital, Palu, } \\
\text { Central Sulawesi }\end{array}$ & $\begin{array}{l}\text { 1) Routine video conference } \\
\text { a) Aiding in the development of a well-defined SOP that is used to manage a neurosurgical patient } \\
\text { during the pandemic; this SOP was adjusted to the current condition of Undata General Hospital } \\
\text { b) By using video conferences, Undata General Hospital could update the latest COVID-19 } \\
\text { information in other centers (both national and international) and how such a condition was } \\
\text { managed by those centers } \\
\text { 2) DSGH aided the development of an emergency operating room in Undata General Hospital; the } \\
\text { hospital was built when Palu was hit by a major earthquake in September } 2018\end{array}$ \\
\hline Jayapura General Hospital, Jayapura, Papua & $\begin{array}{l}\text { DSGH was involved in the creation of hospital guidelines to treat neurosurgical patients during the } \\
\text { COVID-19 pandemic }\end{array}$ \\
\hline
\end{tabular}

The Division of Neurosurgery of DSGH did not hold a routine program with three hospitals (Wates General Hospital, Dr. Midiyato Suratani Naval Hospital, and Muhammadiyah University Hospital) during the outbreak.

first case detected in Indonesia), phase 2 (the first patient reported in the Special Region of Yogyakarta), phase 3 (the curve reaching its peak), and phase 4 (pandemic ceases). ${ }^{6}$ Due to several reasons (e.g., the government's regulations and the availability of PPE), the number of emergency and elective procedures in DSGH was significantly decreased at the beginning of phase 2, reaching its lowest point in May 2020 (Figs. 2 and 3). ${ }^{6}$ This trend was similar to the pattern found in several hospital networks, indicating the similarity of challenges faced by each hospital in Indonesia.

The number of positive cases has increased in recent weeks, reaching 339 cases on July 6, 2020. ${ }^{33}$ However, the number of hospitalized COVID-19 patients passed its peak on May 15, 2020, and since then the number has steadily decreased. In addition, there have been no additional deaths since May 16, 2020 (i.e., 8 deaths). ${ }^{33}$ Therefore, all cities or regents in the Special Region of Yogyakarta were categorized as regions with a low risk of transmission, with the exception of Sleman (i.e., moderate risk; Table 2).

From March 20, 2020, to May 29, 2020, the Provincial Government of the Special Region of Yogyakarta assigned disaster emergency status to Yogyakarta (Circular letter No. 1/SE/III/2020). ${ }^{34}$ This emergency status was different from large-scale social restrictions (Decree of Minister of Health No. 9/2020) in terms of the level of restriction. ${ }^{35}$ This status was continued until June 30, 2020 (Decree of Special Region of Yogyakarta Governor No. 121/KEP, 2020).

\section{Impact of the Partnership With DSGH on the Adaptation of Each Hospital Network}

Our previous article discussed patient management in the emergency department, ambulatory care, in-ward settings, and preoperative preparation for neurosurgical patients. ${ }^{6}$ Also, to improve the management of neurosurgical cases in our hospital network during the pandemic, our center made several changes (Table 3). First, we held a scheduled video conference to review patient care in each hospital during the outbreak. By doing so, we hoped we could learn from others' mistakes or even provide help, if necessary, to any related hospital. We also used the conference to present our approach in patients who needed neurosurgical services during the pandemic. Second, our center also built a more private communication system to the neurosurgeon in several hospitals within our network. This was completed when the related hospital needed more detailed instructions that might be used to manage patients during the pandemic. At some point, the type of shared information might be categorized as confidential and could not be disclosed in a group discussion. Lastly, we sent packages containing PPE (e.g., surgical mask, hazard suit, and face shield) to a hospital with a low supply of PPE (i.e., Yulidin Away General Hospital). The delivery took place in the 3rd week of April, when PPE scarcity was a common occurrence in several regions in Indonesia.

However, two hospitals reported that there were no significant advantages gained from their partnership with 
DSGH. Those two hospitals (Dr. Midiyato Suratani Naval Hospital and Muhammadiyah University Hospital) emphasized the communication issue, in which there were not routine interactions between the two neurosurgeons from those hospitals and our center. Therefore, a commitment has been made between related hospitals and DSGH to increase these interactions, especially by using telecommunication. Nevertheless, this program might be interrupted due to the high workload of both neurosurgeons in those hospitals.

\section{Room for Improvement}

Although several centers gained little, if any, benefit from the relationship with our center in terms of patient management during the outbreak, most hospitals acknowledged that there were positive implications of the partnership with their adjustment process. In the future, it is crucial to build a better communication platform. The application of health informatics support might be beneficial for an AHS. In one center, the electronic health records reconfiguration process with technology-based tools was performed to ease patient management during the pandemic. ${ }^{36}$ Such a process was proven to be beneficial to their AHS during the outbreak.

In addition, the cost of PCR nasal swabs was quite high in Indonesia. Each test costs around US \$95-\$240. ${ }^{37}$ This was considered expensive because the regional minimum payment rate in most areas in Indonesia ranged from US \$120 to \$290 per month. ${ }^{38}$ Therefore, all hospitals within our network still used rapid antibody tests as a screening tool and, in most cases, the PCR test was utilized only if the patient tested positive on the rapid test for SARSCoV-2 antibodies. An improvement of the government's incentive in this sector might be one way to reduce the costs of PCR tests, and AHS UGM should be involved in the advocation process.

\section{Conclusions}

The management of neurosurgical patients during a pandemic is more demanding, and in some cases, created uncertainties among the medical personnel. AHSs help to bridge the gap by disseminating new information or guidelines, establishing a routine communication within the network, distributing essential equipment, and assisting the creation of related SOPs. In addition, the AHS also encourages the use of technology to improve the spread of information to each member in the network. In the future, we expect to develop better collaboration with our hospital network for the next possible pandemic.

\section{References}

1. Coccolini F, Perrone G, Chiarugi M, et al. Surgery in COVID-19 patients: operational directives. World J Emerg Surg. 2020;15(1):25.

2. Zoia C, Bongetta $D$, Veiceschi $P$, et al. Neurosurgery during the COVID-19 pandemic: update from Lombardy, northern Italy. Acta Neurochir (Wien). 2020;162(6):1221-1222.

3. Myles PS, Maswime S. Mitigating the risks of surgery during the COVID-19 pandemic. Lancet. 2020;396(10243):2-3.

4. Indonesian Society of Neurological Surgeons. Recommendation for neurosurgery services during COVID-19 pandemic. Published 2020. Accessed October 15,
2020. http://www.ins.or.id/assets/uploads/news/d67aa-final_ perspebsi-covid_21.04.2020.pdf

5. Jean WC, Ironside NT, Sack KD, et al. The impact of COVID-19 on neurosurgeons and the strategy for triaging non-emergent operations: a global neurosurgery study. Acta Neurochir (Wien). 2020;162(6):1229-1240.

6. Manusubroto W, Wicaksono AS, Tamba DA, et al. Neurosurgery services in Dr. Sardjito General Hospital, Yogyakarta, Indonesia, during the COVID-19 pandemic: experience from a developing country. World Neurosurg. 2020;140:e360e366.

7. Lakhdar F, Benzagmout M. Neurosurgery at war with the COVID-19 pandemic: patient's management from an African neurosurgical center. Letter. Acta Neurochir (Wien). 2020; 162(8):1787-1788.

8. Tsermoulas G, Zisakis A, Flint G, Belli A. Challenges to neurosurgery during the coronavirus disease 2019 (COVID-19) pandemic. World Neurosurg. 2020;139:519-525.

9. Germanò A, Raffa G, Angileri FF, et al. Coronavirus disease 2019 (COVID-19) and neurosurgery: literature and neurosurgical societies recommendations update. World Neurosurg. 2020;139:e812-e817.

10. Anderson G, Steinberg E, Heyssel R. The pivotal role of the academic health center. Health Aff (Millwood). 1994;13(3): 146-158.

11. Washington AE, Coye MJ, Feinberg DT. Academic health centers and the evolution of the health care system. JAMA. 2013;310(18):1929-1930.

12. Roper WL. The role of academic health centers in improving health. Ann Fam Med. 2006;4(suppl 1):S55-S57.

13. Lee VS, Miller T, Daniels C, et al. Creating the exceptional patient experience in one academic health system. Acad Med. 2016;91(3):338-344.

14. Kim CS, Lynch JB, Cohen S, et al. One academic health system's early (and ongoing) experience responding to COVID-19: recommendations from the initial epicenter of the pandemic in the United States. Acad Med. 2020;95(8): 1146-1148.

15. World Health Organization. State Party's self-assessment annual reporting on the implementation of the international health regulations. Published 2020. Accessed October 15, 2020. https://extranet.who.int/e-spar

16. Moore M, Gelfeld B, Okunogbe A, Paul C. Identifying Future Disease Hot Spots: Infectious Disease Vulnerability Index. RAND Corp; 2016.

17. Government of the Republic of Indonesia. Government Ordinance No. 93 year 2015. Published 2015. Accessed October 15, 2020. https://peraturan.bpk.go.id/Home/ Details $/ 5672$

18. Minister of Health Regulation No. 56/MENKES/PER/2014 on Hospital Classification \& Permit. Ministry of Health of the Republic of Indonesia; 2014.

19. Sandelowski M. Whatever happened to qualitative description? Res Nurs Health. 2000;23(4):334-340.

20. Gugus Tugas Percepatan Penanganan COVID-19. Zonation risk data. Published 2020. Accessed October 15, 2020. https: //covid19.go.id/peta-risiko

21. Gugus Tugas Percepatan Penanganan COVID-19. The national trend of COVID-19 (accumulated data per July 6, 2020). Published 2020. Accessed October 15, 2020. https://covid19. go.id/peta-sebaran

22. Indonesian Ministry of Internal Affair. Decree of Ministry of Internal Affair about the productive and safe new normal order for civil servant working in the Ministry of Internal Affair and local government. Published 2020. Accessed October 15, 2020. https://covid19.go.id/storage/app/media/ Protokol/KEPMENDAGRI TENTANG PEDOMAN TATANAN NORMAL BARU.pdf

23. Indonesia CNN. Amid COVID-19 pandemic, Jayapura 
General Hospital drowned by flood. Published April 24, 2020. Accessed October 15, 2020. https://www.cnnindonesia. com/nasional/20200424103801-20-496840/jadi-rujukancovid-19-rsud-jayapura-diterjang-banjir

24. Klompas M. Coronavirus disease 2019 (COVID-19): protecting hospitals from the invisible. Ann Intern Med. 2020; 172(9):619-620.

25. Gugus Tugas Percepatan Penanganan COVID-19. Distribution map of COVID-19 cases in each province. Published 2020. Accessed October 15, 2020. https://covid19. go.id/peta-sebaran

26. Provincial Government of East Java. The number of cases in each regency/city in East Java. Published 2020. Accessed October 15, 2020. http://infocovid19.jatimprov.go.id/

27. Regent for the Local Government of Sleman. Sleman COVID-19 information dashboard. Published 2020. Accessed October 15, 2020. https://covidtracer.slemankab.go.id/ dashboard

28. Indonesian General Surgeon Society. Guideline for general surgery cases during COVID-19 Pandemic. Published 2020. Accessed October 15, 2020. https://drive.google.com/file/d/1 CTL3IdWyHJoAnj3pJjA16HjrxufrH6dM/view

29. Gugus Tugas Percepatan Penanganan COVID-19. Rekomendasi Standar Penggunaan APD untuk Penanganan COVID-19 di Indonesia Revisi 1. Published April 23, 2020. Accessed October 15, 2020. https://covid19.go.id/p/protokol/ rekomendasi-standar-penggunaan-apd-untuk-penanganancovid-19-di-indonesia-revisi-1

30. Anwir FR. Nine regions with COVID-19 red zone status. Published June 2, 2020. Accessed October 15, 2020. https:// www.ajnn.net/news/9-daerah-di-aceh-masuk-kriteria-zonamerah-covid-19/index.html

31. European Association of Neurological Societies. EANS advice: triaging non-emergent neurosurgical procedures during the COVID-19 outbreak. Published 2020. Accessed October 15, 2020. https://cdn.ymaws.com/www.eans.org/resource/ resmgr/documents/corona/eans_advice2020_corona.pdf

32. American College of Surgeons. COVID-19: recommendations for management of elective surgical procedures. Published March 13, 2020. Accessed October 15, 2020. https:// www.facs.org/covid-19/clinical-guidance/elective-surgery

33. Provincial Government of the Special Region of Yogyakarta. The trend of COVID-19 confirmed cases in Yogyakarta. Published 2020. Accessed October 15, 2020. https://corona. jogjaprov.go.id/data-statistik

34. Provincial Government of the Special Region of Yogyakarta. Governor circular letter about COVID-19 disaster emergency status in Special Region of Yogyakarta. Published March 20, 2020. Accessed October 15, 2020. https://corona.jogjaprov. go.id/files/33/Covid19/11/SE-Gubernur-tentang-StatusTanggap-darurat-Bencana-Covid-19-di-DIY.pdf
35. The Indonesian Ministry of Health. Guideline for largescale social restriction in order to accelerate the COVID-19 management. Published April 3, 2020. Accessed October 15, 2020. https://peraturan.bpk.go.id/Home/Details/135220/ permenkes-no-9-tahun-2020

36. Reeves JJ, Hollandsworth HM, Torriani FJ, et al. Rapid response to COVID-19: health informatics support for outbreak management in an academic health system. J Am Med Inform Assoc. 2020;27(6):853-859.

37. Ratriani VR. The cost of rapid antibody and PCR test for COVID-19 detection. Published August 9, 2020. Accessed October 15, 2020. https://kesehatan.kontan.co.id/news/ harga-mulai-rp-17-juta-ini-biaya-rapid-test-dan-swab-test-diindonesia-1?page $=$ all

38. Zuhriyah DA. Regional minimum payment in 34 provinces in Indonesia. Published November 3, 2019. Accessed October 15, 2020. https://finansial.bisnis.com/read/20191103/11/1166176/ ini-daftar-ump-2020-di-34-provinsi

\section{Disclosures}

The authors report no conflict of interest concerning the materials or methods used in this study or the findings specified in this paper.

\section{Author Contributions}

Conception and design: Pramusinto, Tamba. Acquisition of data: Pramusinto, Tamba, Subagio, Numberi, Pramujo, Sinanu. Analysis and interpretation of data: Pramusinto, Ariasthapuri, Bismantara, Meliala. Drafting the article: Pramusinto, Tamba, Bismantara, Meliala. Critically revising the article: Pramusinto, Tamba, Meliala. Reviewed submitted version of manuscript: all authors. Approved the final version of the manuscript on behalf of all authors: Pramusinto. Administrative/technical/material support: Meliala. Study supervision: Meliala.

\section{Correspondence}

Handoyo Pramusinto: Universitas Gadjah Mada, Yogyakarta, Special Region of Yogyakarta, Indonesia.handoyo_pramu@ ugm.ac.id. 